Studia UBB 沺igitalia, Volume 65 (LXV), 2020, June, Issue 1, 53-69

Published Online: 2020-12-10

DOI:10.24193/subbdigitalia.2020.1.04

\title{
DaT18 Database: A Prosopographical Approach to the Study of the Social Structures of Religious Dissent in Mid-Eighteenth-Century Transylvania
}

\author{
Radu Nedici \\ University of Bucharest
}

\begin{abstract}
Drawing on the many records created by the Habsburg state during the confessional troubles in Transylvania from the 1740s to the 1760 s, the DaT18 project merges digital instruments and prosopography to arrive at sketching the social pattern of the Orthodox leadership. This article briefly discusses the technical choices involved in building the relational database that my approach centres on, before talking in more detail about the challenges faced when transposing the information in the primary sources into digital format. First, the question of making use of structured vs. unstructured data, as most of the documents I work with already present some form of tabular layout, while the more narrative ones require different strategies to mitigate losses when converting them. Secondly, the difficult process of record linkage, with many of the persons only mentioned by their first name and no surname to help label each individual entered in more than one source. Lastly, the daunting task of estimating economic resources, since there was no reliable standard in an age that saw four different fiscal systems in use and many regional flavours within the same scheme.
\end{abstract}

Keywords: prosopography, relational database, clerical careers, data structuring, Greek Orthodox Church.

Early modern Transylvania was a land full of contrasts, from social to political and religious, that fuelled one another, leading in turn to the establishment of stricter normative identities. Generally, divergence was kept in check by a system of mutual toleration and an equal distribution of power between the political nations and confessions. Its roots were medieval, but the major elements were set in place during the sixteenth century and they 
were further reinforced once the Habsburgs took over the province at the end of the seventeenth century (Keul; Roth). Conflicts were solved through negotiation and, before the rise of modern nationalism, they rarely broke out into open confrontation. The clashes that involved the Orthodox and Greek Catholic Romanians between the 1740s and the 1760s thereby offer a fertile research ground to expand existing knowledge on the strategies of strife and cohabitation in this part of Europe.

In spite of their number, Transylvanian Romanians were at the margins of the above framework, as they were allowed to have their own religious institution, headed by a recognized bishop of Byzantine rite, but were denied participation in the political life as a distinct estate (Hitchins 14-17). Efforts to increase the standing of the entire community received a boost with the Habsburg rule, since the emperor in Vienna needed to secure collaborators that would help legitimize the Catholic party's claim to power. In exchange for acknowledging religious union with Rome, the Romanians were promised access to the same privileges already enjoyed by the members of the political estates (Bernath 73-82). Both sides pinned high hopes on the resulting Greek Catholic Church, but not much changed after the act of union in 1701. Initially rejected by only a minority, the compromise with Rome came under attack more frequently as decades went by. With the involvement of the Orthodox archbishop of Sremski Karlovci, the conflict entered a new radical stage after 1744. Over the following 17 years internecine violence was rampant, affecting mostly southern Transylvania, where villagers ousted their Greek Catholic priests and replaced them with Orthodox clerics, while petitioning the authorities for the free exercise of religion. The Habsburgs' response, which centred on persecuting the leaders of dissent, failed to temper the spirits and induced the Orthodox Romanians to look for support to their cause outside the borders of the Monarchy, notably to Russia. By the late 1750s, at the height of the Seven Years War, Vienna finally conceded that it lacked the required resources to impose a return to earlier conformity. Tolerance for the Orthodox in the principality was officially proclaimed in 1759 , although they remained the object of discriminatory regulations for at least another century. A separate bishop - Dionisije Novaković was appointed in 1761 to head the newly created diocese in Transylvania, which by that time totalled almost four fifths of all the Byzantine-rite Christians in the province, signalling a glaring defeat for the competing Greek Catholic Church (Nedici, "Religious"; Nedici, "Rethinking"; Nedici, "Cum să pornești").

These two decades of confessional unrest are at the core of my ongoing research project, Dissent and toleration in Habsburg Transylvania: A socio-political history of the Orthodox protests (1740s-1760s), which has received national funding from the Executive Unit for Financing Higher Education, Research, Development and Innovation and is hosted at the University of Bucharest (https://www.dat18.ro, hereafter DaT18). It aims to study the religious troubles in mid-eighteenth-century Transylvania by turning away from the confessional consequences of the split within the Romanian community and on to the social underpinnings and political meanings of the opposition movement itself. Part of the results are now made available in an online database on the project's website, which for now consists of a catalogue of all 
the Orthodox priests active in Transylvania from 1761 to 1767 , with plans to further develop the application to include data concerning the career of leading lay persons. This article will briefly discuss the technical choices involved in building the database, before talking in more detail about the challenges of transposing the information in the primary sources into digital format and readying it for analysis.

\section{Database overview}

Because it is implicit, the behind-the-scenes construction of the new Orthodox eparchy in the 1740s-1760s goes largely unacknowledged in most history texts. To this day, little is known about the men and women behind the spread of dissent and those that emerged as leaders in each village during the troubles and once toleration was announced. Since those at the helm of the protests were mostly common people, able, at best, to just write their names and doing everything they could to avoid suspicion from the Habsburg authorities, their existence is documented in only minimal forms. While there is a tone of information still to be found in the archives, it is scattered and fragmentary, and it usually consists of nothing more than mere names.

The whole rationale behind the project was to somehow arrive at piecing together the many instances when the hundreds and even thousands of anonymous characters were mentioned in order to gain better insights into the social structures of religious dissent. A relational database was best suited for the purpose, as the only instrument capable of exploiting to the fullest the existing sources by linking complementary facts and emphasizing overlapping information, where available. Also, by breaking the data into smaller segments, it becomes possible to selectively and creatively rearrange it an infinite number of times to answer new sets of questions one might ask and to reveal details that the original documents alone did not comprise. Prosopography would in turn allow to move between individual careers and the collective biography of the group to grasp connections and interactions (Keats-Rohan), while at the same time bridging quantitative and qualitative approaches (Cohen et al.).

From a technical standpoint, the database was designed and information was entered in Microsoft Access. This dataset was later imported into Zoho Creator, where the application for querying it was created. I will not go in more detail over the reasons why I opted for such a workflow since I have already addressed them in a conference paper that is forthcoming (Nedici, "Spre o istorie"). The structure of the database was modelled on the equation that each person is mentioned as participating to a historical event only once by the same source, except in the case of obvious errors. This does not impede accounts where the same people were present in more than one circumstance or those where for one separate incident there could be numerous attendants, nor indeed does it deny that different sources may provide contrasting reports on identical facts. However, contextualizing the information passed to the three tables at the core of the database - Person, Event, \& Source - provides equal weight to all the statements and ensures that the accuracy of conflicting details is dealt with at a later stage, instead of being inferred during data entry itself. This is further enhanced by the rule that a record is created only when the person and event are mentioned by a contemporary source, meaning that only first-hand information is 
converted into entities in most cases, while indirect accounts will, at best, provide attributes that are ascribed to something explicitly stated. An appointment for a parish priest, for instance, which also reveals when and where he had been ordained, does not lead to a distinct entry on ordainment alone, but rather this data is placed among the details of his nomination. Additional tables hold values on the standard place names for the individuals' birth and residence and for mapping the facts, as well as on the economic status of those for which the fiscal censuses provide that sort of input. Three further tables are used to link the various entities together, first by creating unique identifiers for the persons and the events, which are then correlated with one another according to existing references (Fig. 1).

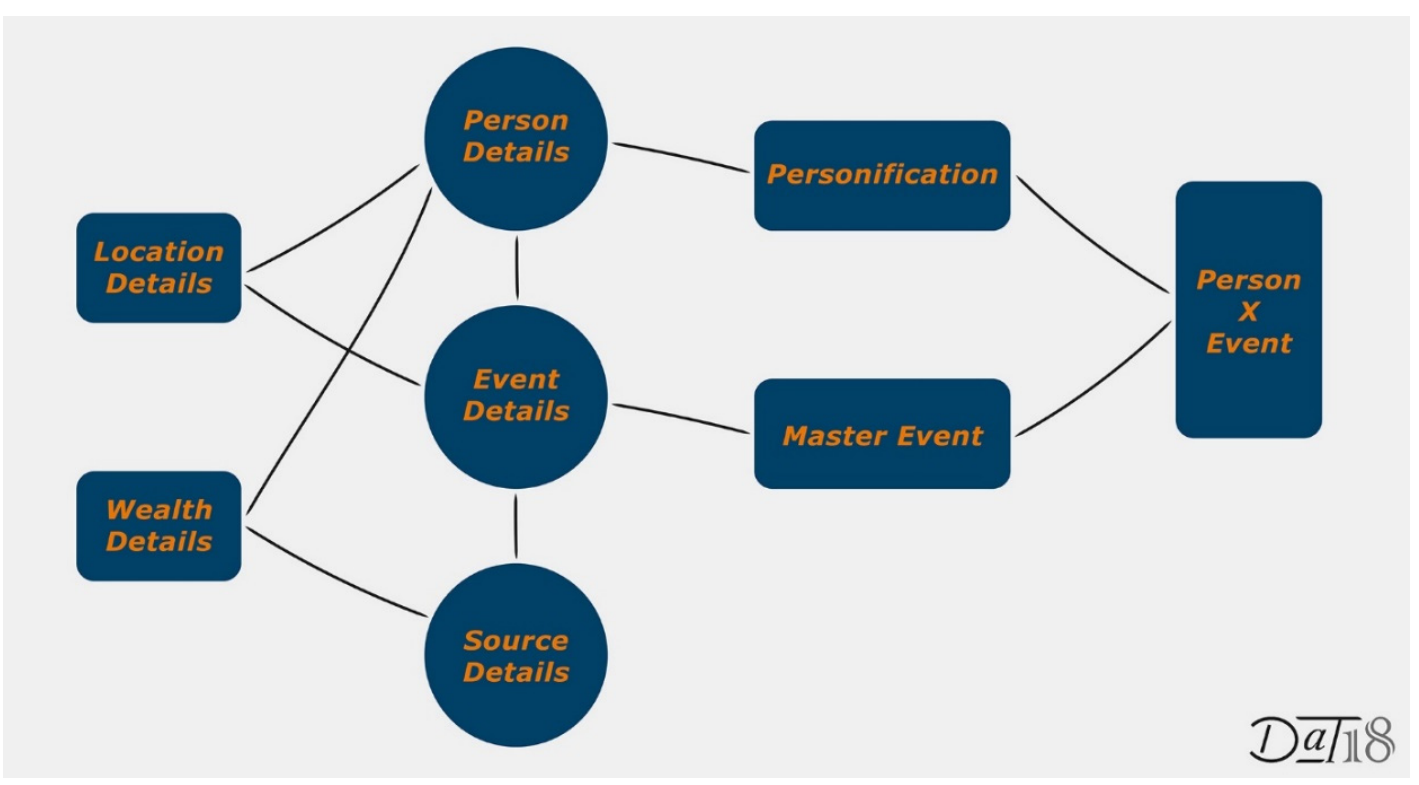

Fig. 1. DaT18 Database logical structure

At the time of writing, the database is at version 3.1, the most recent update being published online in April 2020 ("DaT18 Database"). In line with the objectives set for this stage, it now consists of a complete catalogue of all the parish priests that served in the Orthodox eparchy in Transylvania according to the successive statistics compiled by Bishop Dionisije Novaković from 1761 to 1767 . Access to the database is free for every researcher and does not require any registration before using it. The search interface brings forth two possibilities for querying the metadata, either by using a keyword or by scrolling through the tables that make up the database. The quick search option enables the user to interrogate certain fields in the tables, such as ID, name, event, and location, retrieving all instances that contain the specific term (Fig. 2). Scrolling through each of the main tables allows for a more advanced search, including the use of Boolean operators to narrow the range of results, with only add, edit, and delete functions omitted for obvious reasons (Fig. 3). From the default list view it is possible to navigate to underlying data in other tables by clicking on the highlighted links or to open a detailed view of the object, which already includes relevant information from the related tables (Fig. 4). 


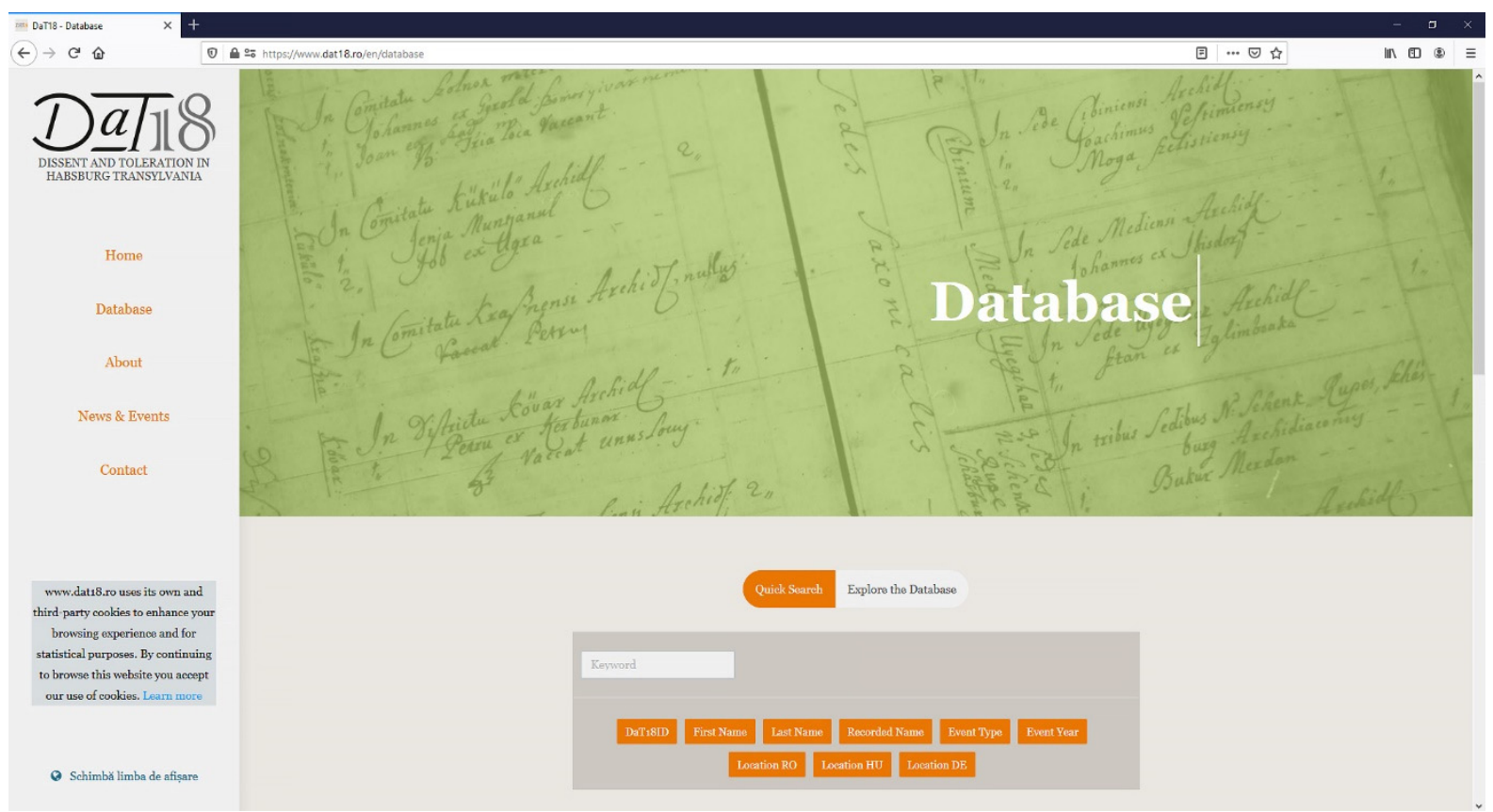

Fig. 2. DaT18 Database quick search interface

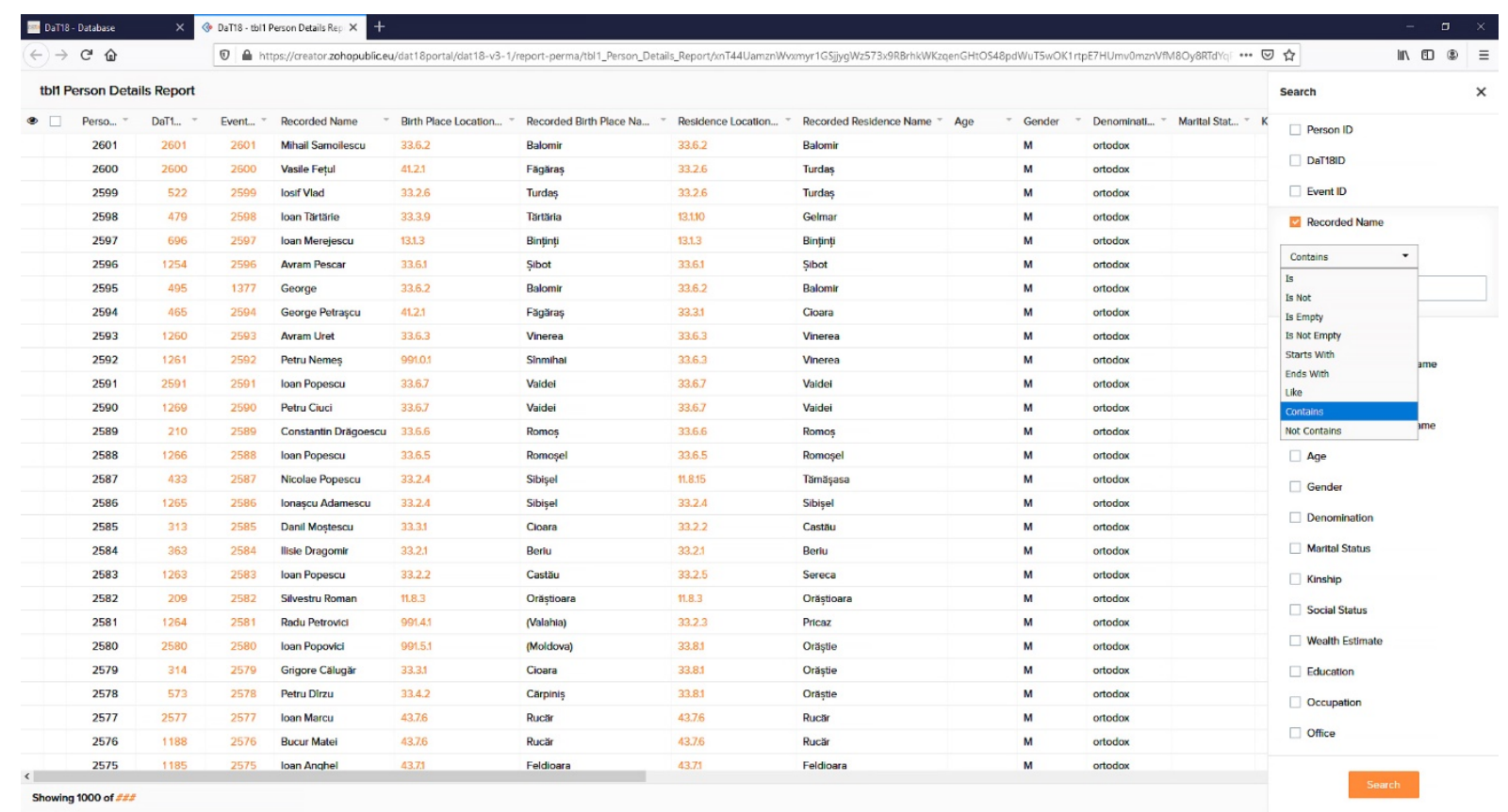

Fig. 3. DaT18 Database advanced search options 


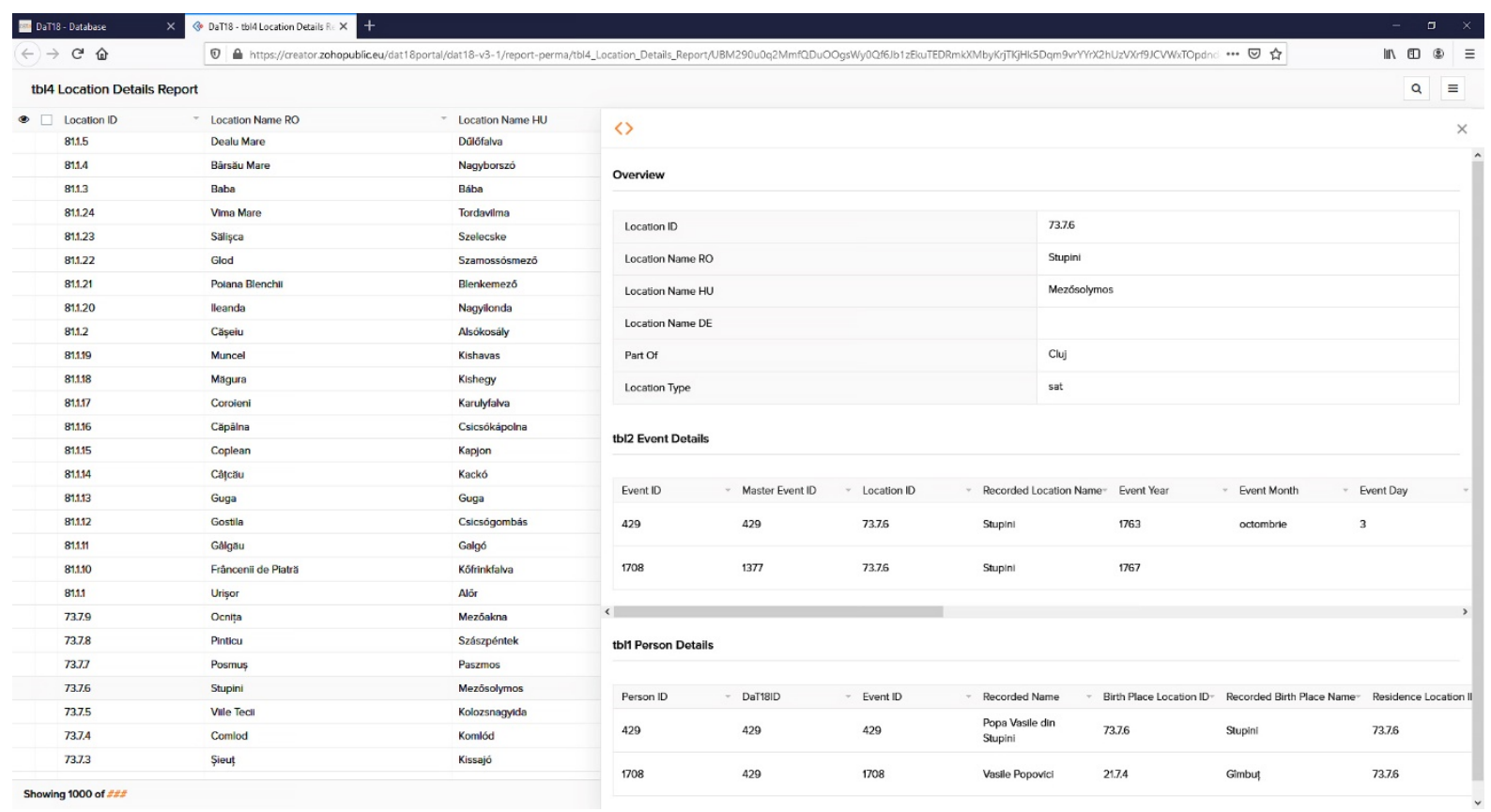

Fig. 4. DaT18 Database detailed record view

\section{Reformatting the sources}

The structuring of digital information was deeply impacted by the sources themselves. While my aim was to always replicate as much of the original data, the heterogenous type of historical evidence I worked with meant that this was not always realistically viable or even possible. Adjustments to the principles described by Townsend et al. (ch. 3) and Mandemakers and Dillon (34-38) had to be made at various stages from data entry to its public release. From the outset of the project then, the purpose has never been to arrive at delivering a digital textual edition of the documents themselves, but rather to develop a structured resource, capable of holding and connecting information from various backgrounds, which would end up enriched by the presence of interdependent data.

Over the first two years of the project I focused on recovering the clerical careers of the some 1,500 Orthodox priests active throughout the 1760s, in an attempt to explain the birth of this social group and its possible roots in the earlier times of religious confrontation. My choice reflected the preservation of significant serial data concerning the clergy, unlike most of the lay leaders of dissent, thus making for more predictable outcomes in the initial stages. Equally important, the problems posed by working with early modern statistical records of church personnel have been the object of close scrutiny by the team behind the Clergy of the Church of England Database, which I reckoned as a distant model (Burns et al.).

Design decisions in building the database have been informed by the direct knowledge and experience of the types of documents susceptible to converge in the final application. In the end, it was all about reaching a compromise between filling-in the details to a general questionnaire that mirrored the avouched intentions of my future analysis and preserving the particularities in every source that was to be so 
recast. This has hopefully resulted in a flexible frame that allows for a systematic extraction of data from the primary sources in order to quantify the spread of dissent, but, at the same time, maintain those details on the life of each individual that should not be overrun by generalizations.

As mentioned previously, much of the historical evidence targeted by the DaT18 project already comprised some form of structured data in the shape of either religious or fiscal censuses. The fields existing or deduced from the common pattern of the records have largely found their way intact into the new tables and their values have been transcribed literally to the database. Breaking down the information into its smallest components posed no problem for certain documents, for instance the staff register used by Bishop Novaković around 1761-1763 to keep track of the ordained clergymen, which only lists the parish and the priest's name, or the few local urbaria that have been included to assess the platform. Nevertheless, in this pre-statistical age census-like records were much less standardized than their modern counterparts, which raises significant issues that go beyond the frequently encountered spelling variations. Even in such a straightforward source as the above-quoted staff list, there are instances when the same person was registered twice and the error left uncorrected, while at other times individuals were first written in and later crossed out of the manuscript (e.g. "DaT18 Database," DaT18ID 660, 1021). In keeping with the requirements of source integrity, I opted to also include them as separate entries into the database, mentioning the anomaly in the notes.

Similarly, the various registers compiled during the eighteenth century still contain much verbiage even when the records conform to a pattern. Take the case of another book covering the period 1762-1767, in which at least three different hands inscribed the priests ordained, appointed, and confirmed by Bishop Dionisije Novaković. Here they no longer employed a tabular form, but rather added complete phrases on every single character, signalling his name, birthplace, parish of residence, ordination and appointment dates, etc. On entry into the database I standardized information except for people and place names and only quoted fragments from the original text in the notes when it said something significant regarding the life events or commented upon the person of the priest. This obviously induced some minor losses compared to the primary source, e.g. in converting relative to absolute chronology, but the trade-off was worth it in terms of data standardization and normalization (Fig. 5). In fact, more alterations were probably due to using the published edition (Hitchins and Beju) instead of the manuscript for harvesting data, although I did run parallel checks to the original and tacitly corrected the more flagrant transcription errors encountered. 


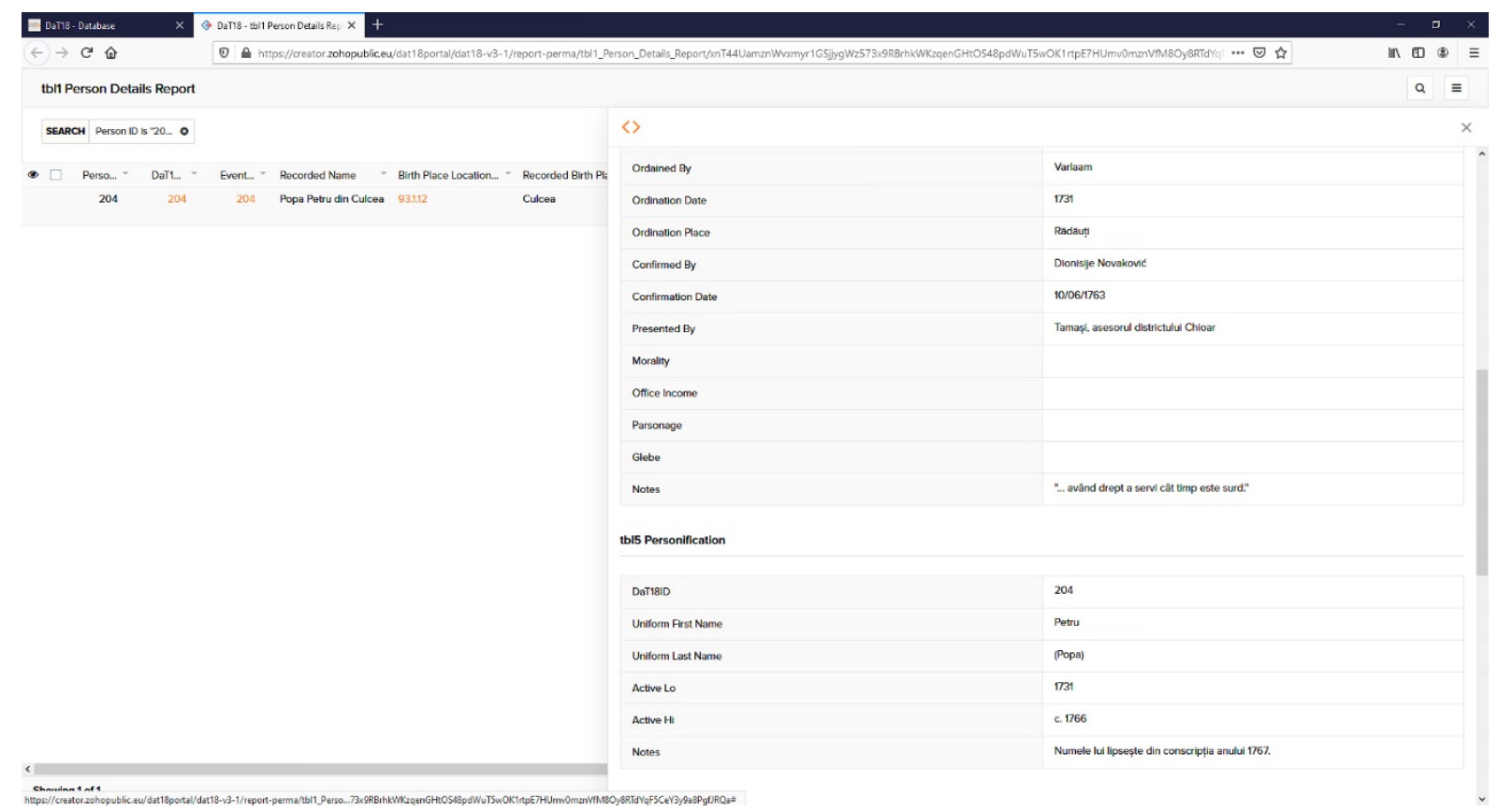

Fig. 5. The use of the notes field in the DaT18 Database

Great disparities exist between information provided by the sources even within the same category and at a few years distance in time, which made it necessary that some details be inferred for the needs of statistical analysis. None of the three major lists that date from the 1760s talk about the gender of the parish priests, for instance. We know that in the Byzantine tradition only male candidates could be ordained, so there is no risk in assuming that the registered clerics were in fact men, in order to distinguish them eventually from the few situations when women were involved in the religious disputes. Likewise, denomination was mostly inferred from the presence on the official roll of Orthodox priests or from the charges brought against the laymen by the authorities, while occupation, which attempts to group the persons in the database in general categories, was filled based on their office, if lacking any positive statements. However, when in doubt, my choice has always been to leave the field empty rather than try and extrapolate something for which there was not enough proof.

Finally, transferring the narrative texts into table format implied an interpretative approach that came with its own norms and limitations. The most detailed sources are the transcripts of the questioning of presumed leaders of dissent, which offer a firstperson account of their earlier life and recent actions, albeit these are to be read with utter consideration for the warnings in the literature (Davis; Farge). They range in length from a couple of pages to a dozen or more and the biographical information is scattered among the many answers. A literal transcription of an entire document would not have been feasible both from the perspective of the time consumed, as well as the formulaic nature of some of the questions and answers that would add nothing to the general knowledge. Besides, it would still not replace the filling-in of values in the predefined fields of the database, which was the absolute requirement. The imperfect solution was to handpick just those bits of information that fitted in the tables, such as 
the names, age, dates, occupation, etc., and insert the detailed descriptions of events in abridged form only. Also, since questioning referenced past occurrences in addition to the latest and offered an unique insight into the perception of the Orthodox themselves on their opposition movement, these have generated multiple entries by exception to the above rule of solely using contemporary material ("DaT18 Database," EventID 1359, 1361, 1365). Supplementing this data with extended citations from the primary source seemed unnecessary at this point, because it would have been unsuitable for taking the research further anyhow. Inputting the information into fixed fields breaks internal relationships within the original text and fundamentally alters its coherence. The succession of questions and answers might seem unimportant for now, but it might pick up relevance later, which is why I decided against placing large inserts from the documents into the database itself.

\section{Personifications}

Record linkage operations were for the most part semi-automatic and simultaneous to data entry, when each person, event, location, and source received a unique ID number that helped establish instant relations between the different entities in the tables. The process was not always that simple and it did require specific skills beyond the reach of artificial intelligence. Due to language and spelling variations in the sources, pinpointing the precise location of places of residence and the events proceeded from information in historical gazetteers, but also involved a basic understanding of philology and geography, aside from some sheer strikes of luck for the most baffling of them. However, once the settlement was identified and the corresponding code attributed manually, the linkage to all other instances in the database was automatic, as was the assignment of standard names and dependencies.

More complicated and delicate resulted the outlining of individuals from the separate entries of persons in the database, for which I borrowed the term employed by Burns et al. to describe what they suggestively penned a "God-like process in which 'people' are created" (732). Personification turns empty names and cold facts into (once) living persons. Although inspired by a common set of goals and principles, the main sources that contribute to the database were not concerned with establishing an absolute identity for the priests they registered, instead focusing on single events that had recently happened or simply attesting their existence. The persons are unique only within the boundaries of the same source and their details are reshuffled for all others. Thus, names employed have a certain meaning for the compilers of the staff register in 1761-1763 but acquire a different value in the census of 1767 . For the purpose of research, down to the basic query based on entering a name as keyword, they had to be structured so that different people could be discerned regardless of them sharing a common name and, likewise, references grouped together when these point to one person under many recorded names. By linking the recurring instances of the same character and providing a unified account of his undertakings, flat pieces of information become three dimensional and restore depth to the clerical careers. 
Personification is subsequent to the input of significant data and constitutes a distinct operation altogether. Individuality is ascribed manually one case at a time by creating a standardized first and last name, by entering the interval of active years based on the earliest and latest records available, supplemented by a notes field that gives a reason if their career terminates before 1767, and also by assigning a unique ID which is to be replicated every time a different record of the same person is encountered. This has allowed for the indexing of 1,676 people distributed over 2,599 personal details' records, of whom 1,619 parish priests. The latter number is still some 150 to 200 individuals above the estimated total clerical figure for the diocese in the period under question, but further identifications are contingent upon unravelling new evidence on the fate of those persons for whom no connections could yet be determined.

The creation of identities rested on two fundamental elements: the recorded name of the priest and the locations he was linked with, whether just his residence or the residence and birthplace together. A name alone is not a strong enough argument for personification, particularly given the specific case of Romanian naming conventions of the time, and even in this combination they do not always work to eliminate all uncertainties. Nevertheless, considering that the database comprises of three different sets of data from a mere seven-year interval and that in the eighteenth century the clergymen rarely transferred from one parish to another, it is within a reasonable margin of error to assume that two or three records a few years apart that document people bearing the same name, functioning in the same parish, and possibly born in the same place are, in fact, multiple instances of one person (Fig. 6).

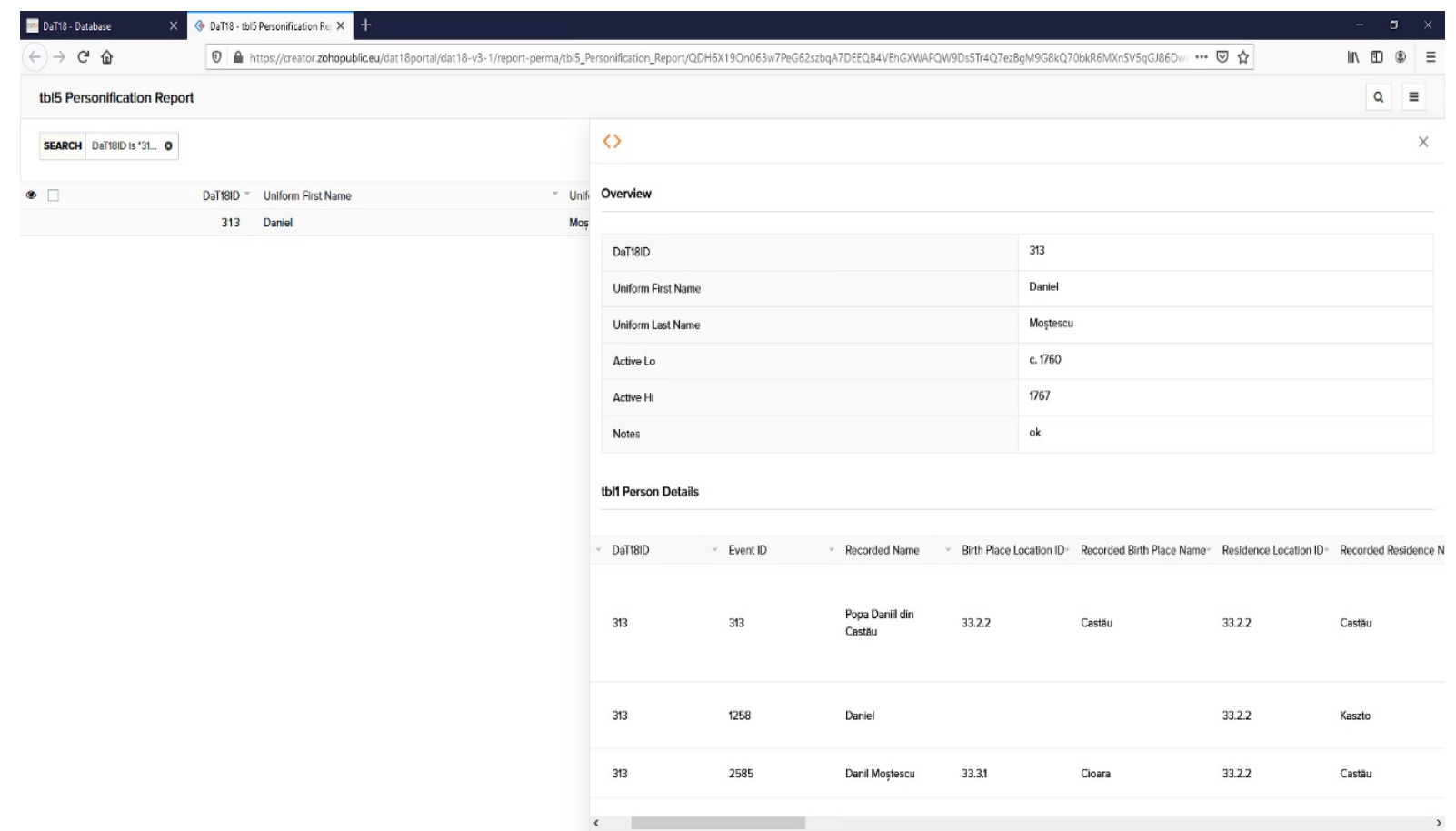

Fig. 6. Name entries variation in the DaT18 Database 
Names or rather the lack of them posed the greatest problems. Priests' surnames only appear regularly in the census of 1767 , while earlier records give the Christian name alone or accompany it with the sobriquet "Popa," i.e. the priest, which efficiently marked the distance from laymen. When a positive identification was possible within the database, the standard last name was created on the pattern of that registered in 1767. This latest form took precedence over earlier records of the surname when they existed, except when previous patronymics or nicknames proved more suitable to distinguish between the bearers of generic surnames such as "Popovici," which is a derivative of "Popa" (e.g. "DaT18 Database," DaT18ID 113, 487, 613).

With only first names to work with, personification would be a nearly hopeless task. More than one fifth of the priests were baptized John or something similar, which hinders any attempt at discriminating between them if the location does not provide sufficient clues. It was already troubling those who entered information into the staff registers more than two and a half centuries ago, which is why they accommodated by either using generational suffixes to distinguish between younger and elder members of the family (e.g. "DaT18 Database," PersonID 1295, 1296) or by alternating the spelling of the names when they repeated for the same parish ("DaT18 Database", PersonID 1193, 1194). However, these distinctions are operational only within the framework of the primary source itself and they do not translate precisely into the next, meaning that such variations cannot prevent personification dilemmas on the whole. Furthermore, if between successive records one of the two persons ceased to exist and none of the previous details were kept with regard to the other, it is impossible to determine which of the parties was still mentioned. Issues with names account thereby for most of the uncertainties that have prevented a higher rate of record linkage.

Locations to which people were connected present obstacles of their own, which add to the already discussed question of spelling and language variants. For one thing, only two of the three main sources concerning the clergy contain a field on the birthplace, which drastically limits the reliability of the assumptions made on those people that share a common name and are known only through their parish of residence. Fortunately, almost half of those concerned by this situation were ordained by Bishop Novaković from 1764 to 1767 and have had little time and reason to change parish until the census in 1767, which confirmed their presence and logged more complete details. On a closer look, the mentioning of the place of origin does not seem an unfailing criterion for judging identities, at least not in the context of the fluctuating records. Far from being substantial, there are nonetheless a worrying number of cases in which the same person is credited with two distinct places of birth, one in the staff register of the early 1760s, the other in the census of 1767 (e.g. "DaT18 Database," DaT18ID 488). Even more doubtful appears the situation of the implicit provenance, suggested by the inclusion in the surname of a settlement designation, which is afterwards contradicted by reference to a different birthplace in the same source (e.g. "DaT18 Database," PersonID 1584). Finally, there are also parish priests who do change residence in the course of time. Again, this does not appear to be a widespread practice, but it is indeed hard to quantify with exact precision the proportion of those involved. While very few of them applied for the permission of the hierarch to do so, 
many others elected to transfer between neighbouring villages over which they probably already exerted authority. It has been possible to operate personifications in the case of those priests that had less common names (e.g. "DaT18 Database," DaT18ID 34), but obviously most escaped any identification since their residences no longer coincided.

All in all, these departures from the bureaucratic practices of record keeping and from the expected behaviour of those who had made the subject of such entries warn us over setting up personifications solely on conjectures. Inconsistencies and equivocal data are intrinsic to early modern sources and the DaT18 project did not try to run counter to that. In this sense, no record linkage was established whenever there was a doubt that could not be resolved. At most, plausible connections were suggested in the notes field of each individual, so that future research would not ignore, but arrive at verifying them.

\section{Fiscal censuses, taxes, and wealth}

Biography alone tells only half the story and it would not take us much further compared to traditional history writing on its own. By electing to focus on the social structures of dissent, the DaT18 project vowed to depart from the common narrative of who did what and when, in order to sketch a fuller and compelling picture of the background against which certain people rose to prominent positions within the opposition movement and the administrative structures of the reborn Orthodox Church. The economic resources of the individuals have been reckoned as an indicator of utmost importance for the prosopography of dissent, since they offer a more in-depth view of inequalities and status in the rural communities than the handful of official categories that segmented the Transylvanian society. Integrating this data is one of the long-term goals of the project and, although they were not a priority at this stage, the database was built to accommodate and make full use of them.

Driven by the quest for reforms of the Habsburg state or owing to the landlords' concerns for managing their estates, censuses became quite common in the second half of the eighteenth century. Apparently at least, the historian is spoilt for choice when it comes to the range of fiscal and economic material at his disposal, mostly still in manuscript in the archives. The final tables of the 1750 general fiscal census alone, the first successful initiative of its kind in Transylvania, span more than 33,000 pages (Gyémánt et al, 1: vii; 2, part 1: xiii), an overwhelming reality that makes the coverage of the entire province impossible for a single researcher. A different strategy will be put in place instead, which involves the careful selection of representative samples, both geographic and in terms of population, for which information will be added to the database. On the other hand, the preservation of the sources is problematic, for the data in the local censuses was made redundant with each new update of the statistics, meaning that they could be more easily disposed off, introducing as a consequence large gaps in chronology and the spatial distribution of these documents. With better survival rates, the state-sponsored censuses were, nevertheless, few and far between, providing only snapshots at the beginning and the end of the period under question, 
which makes obtaining comparable sets of information quite difficult. Plus, given that data collection was to observe the existing exemptions, there is also a high probability that many of the community leaders may have been left outside of the records wittingly, due to their position as parish priests or village elders.

The biggest concern, however, was the lack of any standardized measurement of wealth across the sources. Some focused on the land plots held by each family and on the crops and their potential annual yield, while others registered mainly the livestock. Supplying a monetary value of either tax or income was an exceptional occurrence. Furthermore, since the census takers came inevitably from the ranks of the local administration, their records diverge substantially from one another based on jurisdiction, even when referencing the same categories. Further confusion reigns with regard to the units of measurement, as, for instance, two contemporary records in the Saxon seat of Sibiu alternatively used both shocks and bundles to approximate the harvest of flax and hemp ("DaT18 Database," SourcelD 11, 12). While data would have to be entered into the dedicated table in the database as it were in the primary source, it also had to be somehow converted using a common denominator for it to make sense. Comparing two cows and ten buckets of wine with one acre of land and three pigs to determine which one defines the richest is basically impossible. Hence the idea to use the methods employed by the Habsburg bureaucracy itself to assess a global figure for the taxes owed by the households and rely on it for any subsequent calculation.

There was no definitive model to start with, for in little less than three decades Transylvania experienced four different fiscal systems, passing from the traditional division on fiscal gates and calculi of pre-1753 to individual taxation according to the scheme proposed by Gábor Bethlen in 1754 and later revised by Adolf Nikolaus von Buccow in 1763 and Samuel von Brukenthal in 1769 (Trócsányi 590-596; Ionaș). The later three methods exchanged various formulas for calculating the due contributions that comprised of both a poll tax and money levied on assets and income. The poll tax grouped taxpayers into fiscal classes, which varied according to their social and economic status as well as their residence, but proved difficult to implement fairly and consistently, leading to corrective interventions and to further segmentation of the initial categories.

While revisions were also the norm for the taxes on assessable property and revenue, the definition of specific goods that were subject to taxation stayed constant for longer, with only their value changing over time. Table 1 below offers an overview of these differences across the three fiscal systems that went in successive use in the 1750 s and 1760 s. To some degree the naked figures are misleading, for they fail to disclose the entire complexity of the transformations, which impacted significantly how the landed property was taxed. The arable land was classified into four categories according to productivity and a rate was set for each, with further differentiation for vineyards and meadows. At first, the charge was on the actual crop, but it soon emerged that this practice forced the peasants to abandon some of their fields in order to pay less, and so, starting with the implementation of the Buccow- and afterwards the Brukenthal-system, the rate was linked to the surface of the plot, changing not only the amount, but the very substance of what was recorded in the tax rolls. 
Table 1

Comparative overview of the tax amounts levied on property and income in Transylvania after 1754 (all figures in kreuzer).

\begin{tabular}{lllllllllll}
\hline \multirow{2}{*}{ Fiscal system } & $\begin{array}{l}\text { Land tax / } \\
1 / 3 \text { acre }\end{array}$ & $\begin{array}{l}\text { Oxen / } \\
\text { head }\end{array}$ & $\begin{array}{l}\text { Cows / } \\
\text { head }\end{array}$ & $\begin{array}{l}\text { Sheep / } \\
\text { head }\end{array}$ & $\begin{array}{l}\text { Pigs / } \\
\text { head }\end{array}$ & $\begin{array}{l}\text { Wine } \\
\text { bucket }\end{array}$ & $\begin{array}{l}\text { Hay } \\
\text { cart }\end{array}$ & $\begin{array}{l}\text { Revenue } \\
\text { / 1 Rfl. }\end{array}$ \\
\hline Bethlen & $8-20$ & $30-40$ & $20-27$ & $3-4$ & $3-4$ & $0.75-1$ & $1.5-2$ & $3-4$ \\
Buccow & $9-18$ & 24 & 20 & 3 & 5 & 3 & 5 & 5 \\
Brukenthal & $8-20$ & 24 & 20 & 3 & 5 & 3 & 6 & 6 \\
\hline
\end{tabular}

Source: Author's own elaboration based on data in Bozac and Pavel (395-398).

The introduction by Bethlen of a tax-unit called cubulus, although soon abandoned by the following systems, was in hindsight a sensible choice when trying to equate objects that did not lend themselves easily to comparison. Except for crops, everything else from wine, hay, animals, to even revenue obtained from running mills, lending out properties, or selling brandy were each considered to be worth a certain amount of cubuli based on their market and approximate relative value, so that, for instance, 2 oxen were the equivalent of 3 cows or 20 sheep, pigs or bee hives, and of 40 wine buckets (lonaș 81). A conversion rate of 3 kreuzer (4 in the case of the Saxons) to cubulus was then applied to calculate the tax liabilities of any given household. Later systems improved upon this model, as they dropped the cubulus and made all calculations directly in guldens, while also levelling the taxes between the inhabitants of the counties and those in the Saxon seats and altering at times radically their base value for better balancing between the various goods.

Despite its ultimate rejection by contemporaries, the cubulus makes arriving at meaningful values relatively straightforward for simple estimates of wealth. Not only did it cover an entire decade right in middle of the timeframe targeted by the DaT18 project, but this artificial tax-unit has also the merit of expressing economic resources into decimal format, thus sparing the trouble of working in guldens and its subdivisions, the equally factitious money of account of the Monarchy.

In a further effort to reduce the variables, I set out to only consider the animal stock as the most common indicator of wealth. At a time when much of the rural population only possessed a house with a scant inventory and a plot of land to feed themselves, the animals could count as the real differentiator. More draft animals made farming easier and meant that additional land could be claimed for cultivation by members of the same household, while an above average number of livestock signalled a diversification of income from selling the surplus products to the market. Regardless of the fiscal system in use or the purpose for taking the census, whether general or local, animals were almost never absent from the records. They were already understood as a distinct tax category by all three systems of the age. And, unlike in the case of wine and hay, which become harder to quantify in the $1760 \mathrm{~s}$, 
counting them could hardly lead to massive differences of scale, though tax evasion did pose a serious threat to any realistic estimates, as eighteenth-century authorities were well too aware.

To sum things up, the table on wealth translates exactly the information in the primary sources, whether it concerns the estimated crop, the animal heads in one's possession, the structure of income, and even debts and exemptions. It then employs a simple formula for calculating the cubulus value of the animal stock and exports this figure to a field in the personal details page that is used to assess the economic value of the individual in relation to his peers in the database. By focusing on a limited amount of data and transposing it in a common format that is both consistent with the period and with our modern needs, the whole estimate is kept within some manageable limits.

\section{Final considerations}

The digital medium changes little in terms of the research routine of the historian. While the range of programming skills is ultimately optional in an industry that is more and more collaborative, the decisions I was faced with during the development of the database were not at all different from those I would have confronted in a more traditional setting. As always, the main dilemma centres on how to make the original sources answer questions on topics they were not initially intended to speak about, yet which they encompass. The DaT18 Database took shape as one possible solution to break the silence that the men and women at the helm of the religious protests in Transylvania kept on themselves for too long.

At the same time, prosopography and the relational database that provides the underlying data for it is just one piece in a wider approach aimed at interpreting the Orthodox dissent in Transylvania using the methods of social history and, equally important, reassessing the political practices of the subordinate categories involved in the opposition against the Greek Catholic Church. Constant improvements and updates are for certain needed to ensure the viability of the platform, but so is the actual investigation that motivated it in the first place. The database is nothing more than an instrument of research, the digital content assisting to open up new possibilities of interpretation. At the end of the day though, it remains the task of the historian to employ the best methods of his craft to arrive at a compelling scholarly analysis, which is not replaced, but rather augmented by the new medium.

\section{Acknowledgement}

This work was supported by a grant of the Ministry of Research and Innovation, CNCS - UEFISCDI, project number PN-III-P1-1.1-PD-2016-0296, within PNCDI III. Special thanks go to Oana Sorescu-ludean and to Vlad Popovici for all their critical comments at various stages of my project, as well as to the anonymous reviewers who provided helpful suggestions on a first draft of the manuscript. 


\section{Works Cited}

Bernath, Mathias. Habsburgii și începuturile formării națiunii române. Translated by Marionela Wolf, Editura Dacia, 1994.

Bozac, Ileana, and Teodor Pavel, editors. Călătoria împăratului losif al II-lea în

Transilvania la 1773 / Die Reise Kaiser Josephs II. durch Siebenbürgen im Jahre 1773. Vol. 1, Institutul Cultural Român - Centrul de Studii Transilvane, 2006.

Burns, Arthur, et al. "Reconstructing Clerical Careers: The Experience of the Clergy of the Church of England Database." The Journal of Ecclesiastical History, vol. 55, no. 4, 2004, pp. 726-737.

Cohen, Gidon, et al. "Towards A Mixed Method Social History: Combining quantitative and qualitative methods in the study of collective biography." Prosopography Approaches and Applications: A Handbook, edited by K. S. B. Keats-Rohan, Occasional Publications of the Unit for Prosopographical Research, 2007, pp. 211-29.

"DaT18 Database." Dissent and toleration in Habsburg Transylvania: A socio-political history of the Orthodox protests (1740s-1760s), Version 3.1, 2018-2020, https://www.dat18.ro/en/database. Accessed 12 May 2020.

Davis, Natalie Zemon. Fiction in the Archives: Pardon Tales and Their Tellers in Sixteenth-Century France. Stanford University Press, 1987.

Farge, Arlette. Le goût de l'archive. Éditions du Seuil, 1989.

Gyémánt, Ladislau et al., editors. Conscripția fiscală a Transilvaniei din anul 1750. Univers Enciclopedic, 2009-2016. 2 vols in 5 parts.

Hitchins, Keith. The Idea of Nation: The Romanians of Transylvania, 1691-1849. Editura Științifică și Enciclopedică, 1985.

Hitchins, Keith, and loan N. Beju, editors. "Documente privitoare la trecutul Bisericii Ortodoxe Române din Transilvania după 1761." Mitropolia Ardealului, vol. 19, nos. 1-3, 1974, pp. 13-46.

lonaș, Vasile. "Reformele fiscale din Transilvania în secolul al XVIII-lea." Annales Universitatis Apulensis, series Historica, vol. 4-5, 2000-2001, pp. 79-90.

Keats-Rohan, Katharine. "Prosopography and computing: a marriage made in heaven?" History and Computing, vol. 12, no. 1, 2000, pp. 1-11.

Keul, István. Early Modern Religious Communities in East-Central Europe: Ethnic Diversity, Denominational Plurality, and Corporative Politics in the Principality of Transylvania (1526-1691). Brill, 2009.

Mandemakers, Kees, and Lisa Dillon. "Best Practices with Large Databases on Historical Populations." Historical Methods: A Journal of Quantitative and Interdisciplinary History, vol. 37, no. 1, 2004, pp. 34-38.

Nedici, Radu. "Cum să pornești o revoltă în veacul al XVIII-lea: Activism, adunări publice și propagandă în comunitățile ortodoxe din Transilvania (1740-1760)." Revista Istorică, vol. 28, nos. 5-6, 2017, pp. 479-98.

- "Religious violence, political dialogue, and the public: the Orthodox riots in eighteenth-century Transylvania." Economy and society in Central and Eastern Europe: Territory, population, consumption, edited by Daniel Dumitran and Valer Moga, LIT Verlag, 2013, pp. 87-100. 
_. "Rethinking religious dissent in mid-eighteenth-century Transylvania: Political practices and the plebeian public sphere." Analele Universității București: Istorie, vol. 63 , no. 1, 2014, pp. 101-24.

- "Spre o istorie socială a disidenței religioase: Un inventar al surselor referitoare la protestele ortodocșilor din Transilvania de la mijlocul secolului al XVIII-lea." Sursele unei istorii (pre)moderne românești în Moldova și Valahia, 21 September 2018, Institutul de Istorie 'Nicolae Iorga', Bucharest. Conference Presentation.

Roth, Paul W. "Das Diploma Leopoldinum: Vorgeschichte, Bestimmungen." Siebenbürgen in der Habsburgermonarchie. Vom Leopoldinum bis zum Ausgleich (1690-1867), edited by Zsolt K. Lengyel and Ulrich A. Wien, Böhlau Verlag, 1999, pp. $1-11$.

Townsend, Sean, et al. "Digitising History: A Guide to Creating Digital Resources from Historical Documents." AHDS Guides to Good Practice. University of Essex, 1999, http://hds.essex.ac.uk/g2gp/digitising_history/index.asp. Accessed 12 May 2020.

Trócsányi, Zsolt. "A New Regime and an Altered Ethnic Pattern (1711-1770)." History of Transylvania, vol. 2, edited by László Makkai and Zoltán Szász, Social Science Monographs, 2002, pp. 515-618. 